\title{
Political Culture
}

\author{
FILIPE CARREIRA DA SILVA \\ University of Lisbon, Portugal \\ TERRY N. CLARK \\ University of Chicago, USA \\ MÓNICA BRITO VIEIRA \\ University of York, UK
}

Political culture refers to the values and political conduct of individual or collective agents. As a concept it is as old as the analysis of politics itself. Aristotle wrote about a "state of mind" that could inspire either political change or stability; Machiavelli stressed the role of the values and feelings of identity and commitment; Burke praised the "cake of custom" that enabled political institutions to fulfill their aims; Tocqueville emphasized moeurs as the key determinants of the character of a particular society. But the contemporary understanding of political culture has been uniquely influenced by Gabriel Almond and Sidney Verba's classic behaviorist formulation in The Civic Culture (1963), leading up to today's multicausal, relational, and mixed methods approaches to the study of the concept (Thompson, Ellis, \& Wildavsky, 1990). As a result of this methodological diversity, political culture has ceased to be narrowly identified with the attitudes toward government of political agents, to be measured in the aggregate and then compared across political systems, or even more broadly conceived as a process in which political meaning is constructed in the interplay between the attitudes of individual citizens and the language and symbolic systems in which they are embedded. Contemporary analysis of political culture is a broad church, taking in everything from data collection on political opinions, attitudes, and values conducted by means of structured interviews with representative samples of citizens (e.g., Inglehart, 1997), to interpretive approaches that use a range of qualitative methods to clarify how political identities are generated, or how symbols and rhetoric can generate compliance or conflict, to discussions of why some ethnic identities become radicalized and others do not. The field has become so broad, that it is hard to pinpoint what is political culture and what is not.

\section{The behaviorist postwar revolution}

Almond and Verba's pioneering study of political culture, The Civic Culture (1963), is as much a reflection of the dominance of behaviorist and functionalist approaches in the postwar period as it is a reaction against the legal institutionalist paradigm that had commanded political science since the end of the 19th century. Some historical events were also important in promoting awareness of the special interest of political culture as a research topic. For instance, the collapse of constitutional regimes in Germany, Italy,

The International Encyclopedia of Political Communication, First Edition. Edited by Gianpietro Mazzoleni. ๑ 2015 John Wiley \& Sons, Inc. Published 2015 by John Wiley \& Sons, Inc.

DOI: $10.1002 / 9781118541555$.wbiepc161 
and Spain in the 1920s and 1930s raised questions as to the adequacy of institutionalist analyses that had predicted the gradual spread of liberal democratic regimes and enlightenment values. A typical product of the political sociology of 1950s and early 1960s, in that it sought to catalogue and reproduce the conditions for the expansion of representative democracy, The Civic Culture rapidly soon gained the status of a classic. It is also a classic that confines rather than expands disciplinary understandings. In the work, political culture comes narrowly defined as the "pattern of orientations" to political institutions, conventions, and traditions, which include parties, courts, constitutions, and the history of the country. Orientations are predispositions to political action and are determined by a vast set of factors, including tradition, historical memories, norms, emotions, and symbols. Such orientations are the result of cognition (knowledge and awareness of political objects), affection (emotions and feelings about the object), and evaluation (judgments about those objects).

Almond and Verba proceed to articulate the concept of political culture empirically in sample surveys that they apply in five democratic countries: the United States, Mexico, Great Britain, Germany, and Italy. The Civic Culture's major empirical finding is the identification of three different types of political culture, resulting in a typology on which a theory of the cultural bases of stable democracy was to be erected. The first type is the parochial political culture, characterized by a prevalence of attitudes based on particularism, localism, interpersonal trust, and a subjective separation from the state and politics. Failed states such as early 21 st-century Somalia, where warlords ruled without an established central authority, illustrate this cultural type. The second type is the subject political culture, whose central feature is compliance and confidence in the legal authority of the state. It is illustrated by feudal societies, where individuals are subjects with duties (such as paying taxes) but with few rights (unlike citizens, subjects do not have political rights, for instance). The third type is the participant political culture, in which the citizen is an active participant in the political process, either supporting or rejecting government decisions. Modern democracies illustrate this type of political culture.

Although acknowledging that this typology admits numerous variations, with countries easily moving in and out of its categories, Almond and Verba conclude that "civic culture" constitutes a good balance between these three ideal types and is the most adequate cultural foundation for a stable democracy. Of the five countries analyzed, only the United States and Great Britain are deemed to have a civic culture. Italy's parochial political culture and Germany's subject political culture are considered to offer the basis for democracies with a high risk of instability. Some of these findings were reviewed and criticized 20 years later by Almond and Verba themselves in The Civic Culture Revisited (1980). Whereas, they suggest, in Germany subject attitudes gradually gave way to a more participatory culture, in Britain and the United States the levels of distrust and dissatisfaction increased significantly. This pattern of intergenerational value change has been corroborated by several other studies.

The impact of Almond and Verba's research program in the comparative study of political culture has been substantial. The research design originally adopted in The Civic Culture, sample surveys applied in different countries (comparative design) and 
in the same countries in different years (longitudinal design), has inspired the establishment of a number of agencies to monitor social and political attitudes. The General Social Survey is a public opinion survey conducted in the United States nearly every year since 1972. The European Union established the Eurobarometer in 1973. In 1991, in the wake of the fall of the Berlin Wall, the New Democracies Barometer was set up to study 12 Eastern European countries. More recently, Latin America and Africa were included in this international effort: the Latinobarometer was created in 1996 and the Afrobarometer 3 years later. In addition, the World Values Survey and the European Values Survey have conducted five waves of data collection since 1981, with more than one hundred countries covered in the most recent wave (2005).

However, a number of conceptual and technical difficulties beset the conception of political culture as a reflection of individual attitudes which underpins survey-based studies. One such difficulty is the "individualistic fallacy," which involves drawing conclusions as to the collective characteristics of a group from the aggregated features of individuals. The source of this difficulty is the atomist assumption of the behaviorist approach that the whole equals the aggregation of its individual parts. Although data collection is centered on the respondent/individual microlevel, culture is a collective phenomenon. The proportion of respondents who express their support for democratic values does not tell us how "democratic" the political culture is; only that a certain proportion of the population thinks in such a way. To study how democratic a political culture is, one needs to acknowledge its collective character and adjust the theoretical and methodological strategy accordingly.

\section{Tocqueville rediscovered}

Robert Putnam's (with R. Leonardi and R. Nanetti) seminal study of political cultures in Italy, Making Democracy Work (1993) is an attempt to move beyond the methodological individualism of the behaviorist approach. The introduction of regional governments in Italy in the 1970s provided Putnam with an excellent opportunity to study variance in institutional performance: What explained the differences in the output of the different regional governments within the same nation-state? Putnam's answer to this question is indebted to Alexis de Tocqueville's analysis of the political effects of associational life in the United States and marks a radical shift in the contemporary study of political culture.

This shift starts with Putnam's adjustment of his methodological strategy to an expanded notion of political culture. Making Democracy Work resorts not only to elite and mass surveys but also to data gathered from official documents and historical archives on involvement in voluntary and other associations, newspaper circulation figures, and election turnout. Putnam starts by showing that the substantial differences in institutional efficiency he finds are not explained by differences in the economic development of the northern and the southern regions. That this is a spurious correlation becomes apparent as soon as Putnam's main independent variable is included: social capital, a collective resource that "refers to features of social organization, such as trust, norms and networks that can improve the efficiency of society by facilitating 
coordinated actions" (1993, p. 167). The social capital present in the various Italian regions in the early 19th century explains many differences in economic development by the late 19th century, and then institutional performance of governments by the late 20th century. Although northern regions had higher levels of social capital but similar levels of poverty than the southern regions at that time, 70 years later those differences in social capital account for Italy's wealth divide between north and south. The economic differences between these regions are not the cause but a consequence of a more complex divide, between the northern regions, with a high social capital and high institutional performance, and the southern regions, with limited social capital and inefficient regional governments. This thesis is supported with historical/archival materials as well as regressions controlling several possible competing variables.

Putnam's findings are an important complement to previous studies of Italian political culture. These include not only Almond and Verba's The Civic Culture but also contemporary ethnographic fieldwork of Edward Banfield in The Moral Basis of a Backward Society (1958), which introduced "amoral familism" as an explanatory factor. Putnam's neo-Tocquevillian approach suggests Italy to be a case of a divided political culture in which cultural divisions coincide with geographical ones. In northern Italy, the civic community, which corresponds to the participant political culture, predominates. In the southern regions, this is replaced with parochialism, characterized by localist and familistic loyalties (i.e. the vicious circle of the uncivic community). This, in turn, calls attention to the fact that political culture includes beliefs and attitudes that do not have an explicit political content or orientation; they are embedded in broader values about, and patters of relation within, family, church, and more. Even though the political meaning and consequences of "amoral familism" and parochialism are implicit and embedded, they are just as important as the explicit political content of participant and subject cultures for explaining different outcomes in Italy.

\section{The New Political Culture}

Influential as it is, Putnam's neo-Tocquevillian approach is but one of the new strands of research on political culture that developed in the end of the 20th century. Another influential line of research focuses on changes in political culture and, in particular, on the rise of a new constellation of political values and beliefs - the New Political Culture (NPC).

This original blend of social liberalism and fiscal conservatism was first identified in the 1970s urban America. The question of what drives the shift toward the NPC has driven the research program. Terry Nichols Clark and Vincent Hoffman-Martinot have identified seven general elements of the NPC: (1) the classic left-right dimension has been transformed, with immigration, women, and many new issues no longer mapping onto one single dimension; (2) social and fiscal/economic issues are explicitly distinguished, work no longer driving all of them; (3) social and cultural issues like identity, gender, morality, and lifestyle have risen in salience relative to fiscal/economic issues; (4) market individualism and social individualism have both grown, with people seek-

ing to mark themselves as distinct from their surroundings; (5) the postwar national 
welfare state looses ground to federalist and regionalist solutions; parties, unions, and established churches are often replaced by new, smaller organizations that may join into social movements (6) instead of rich versus poor, or capitalisms versus socialism, there is a rise of issue politics - of the arts, the environment, or gender equality - which may spark active citizen participation on one such issue, but each issue may be unrelated to the others; (7) these NPC views are more pervasive among younger, more educated, and affluent individuals and societies (Clark \& Hoffmann-Martinot, 1998). Multicausal approaches typically combine survey data with a vast range of other materials, including socioeconomic indicators, official documents, oral history, and ethnographic descriptions. One of its strands, developed in the tradition of the Chicago School of sociology, has recently evolved into a general theory of "scenes," each with its own rules of the game (Silver, Clark, \& Yanez, 2010).

Ronald Inglehart's 1977 The Silent Revolution, using data from public opinion surveys in European Community countries, Switzerland, and the United States, documents a similar fundamental shift in the values and political skills of western publics throughout the 1960s and 1970s, from an overwhelming emphasis on material well-being and physical security toward a greater emphasis on quality of life. Inglehart designates this new set of values as "postmaterialist," following the theory of motivation developed by the psychologist Abraham Maslow (who sometimes used other terms like postmodernist). Inglehart considers postmaterialist value orientations to be the effects of the experience of economic well-being. This had played an active role in the socialization of young people, notably in Western Europe, which had enjoyed an unprecedented level of wealth since World War II. More recently, in Modernization and Postmodernization (1997), Inglehart shows the extent to which culture can be a major variable in explaining democracy and postmodernization. The findings of this major cross-national study indicate that a diverse set of western countries, including northern European, English-speaking and Catholic European countries, are moving toward postmodernization, which, much like postmaterialism, entails a rejection of traditional values and forms of authority that were part of the "class politics" of the modernist industrial age. Abortion, divorce, homosexuality, prostitution, extramarital sexual relationships, euthanasia, suicide, and recreational drugs are social issues central to postmodern publics, who are also less attached to formal religions and are less likely to attend church. There are important regional differences, however. In countries such as Turkey, Nigeria, South Africa, and India individuals are more concerned with materialist values than with experimenting with postmaterialist ones. Brazil, Mexico, Chile, and Argentina fall somewhere in the middle of the spectrum of scarcity values, traditional authority, and postmodernization. China, Japan, and South Korea are similarly oriented toward economic achievement but differ greatly in democracy rankings, with Japan and South Korea exhibiting westernlike postmodernization values that cannot be found in China.

Cross-national studies such as Modernization and Postmodernization tend to assume the internal homogeneity of each country as survey data is collected at the level of the nation-state (on the problem of "methodological nationalism"; see Beck, 2000; Martins, 1974). A celebrated attempt to circumvent this problem in political culture research is 
Daniel J. Elazar's analysis of the United States as a laboratory where the strands of different European cultures confront each other, combine, and spread: northern European Puritan communalists, middle European individualists, southern plantation managers (1975). More recently, drawing on a culturalist reading of Durkheim, Jeffrey Alexander and Phillip Smith have proposed the notion of a "discourse of American civil society" that is at the basis of the different subcultures that characterize American politics. Concretely, they claim there is an "underlying consensus as to the key symbolic patterns of American civil society" (1993, p. 165), at the heart of which lies a fundamental set of "democratic" and "counterdemocratic" binary codes amenable to interpretive empirical analysis. Alexander's Civil Sphere (2006) is the most ambitious and detailed application of this neo-Durkheimian approach to political culture to date.

\section{Political culture analysis today}

The landscape of political culture analysis today features several competing approaches. The dominant perspective is the comparative survey approach inaugurated by The Civic Culture half a century ago. It has shaped the disciplinary understanding of what political culture is and how it should be studied in important ways. As a result of it, political scientists gained a powerful methodological instrument to conduct rigorous longitudinal, comparative analyses of political communities across the globe. Its main difficulty lies in its methodological individualism, which equates political culture with aggregate individual attitudes toward government.

Other approaches, such as Putnam's neo-Tocquevillian approach, have a broader understanding of political culture that includes non-political beliefs pivotal to the construction of political meaning. Their influence is undoubted. Concepts such as "social capital" and "trust" became the buzzwords of early 21st-century political science, inspiring a wealth of empirical studies of associational life. Implicit in most of these studies, however, is the notion that there is one ideal model of democracy (e.g., Putnam's "civic community" or Almond and Verba's "participant political culture") that acts as the analytical yardstick that all other political cultures are to be measured against. Unsurprisingly, given the intellectual roots of these approaches, the implicit democratic ideal is the New England town-meeting model of democracy (see Putnam, 2000). But its continuing relevance in the face of multiple transformations demands clarification.

Multicausal approaches to cultural change try to avoid this bias by expanding the scope of norms of citizenship with which the Putnam-Tocqueville model usually operates (Clark \& Silva, 2009). One subset of political culture includes the norms of citizenship, which encompass the values and representations individuals have of their relation with democratic authorities qua citizens. Empirical political scientists have identified several different norms of citizenship in the United States and Europe. These include besides the "duty-based" norm of citizenship (the neo-Tocquevillian ideal-typical culture), the "engagement" and the "solidarity" norms of citizenship (Dalton, 2008; Denters, Gabriel, \& Torcal, 2007). These three civic norms are the product of socioeconomic change. Other norms of citizenship reflect a different type of cleavage. The cleavage 
between identity politics and the rule of law, for instance, generates "thick" or "identitybased" norms of citizenship as opposed to "thin" or "legal-civic" ones (Lewis-Epstein \& Levanon, 2005). The common aim behind these studies is to provide a more nuanced and complex understanding of global differences in political culture.

Macro-structural theories building on Marx, Weber, and Durkheim have been joined with microdynamics of citizens and small groups, in the work of theorists like Jürgen Habermas, Hans Joas, and Bruno Latour. All of them have been seeking to construct a more integrated analytical framework where changes can be driven at many levels (Silva, 2008), whose intersections are complex. The multiple identities of individuals linked to multiple overlapping memberships weaken strong identities (like the proletarian and their explanatory power) while they also encourage more cosmopolitanism or hybridism. One extension of this led to a strong postmodernism, which suggested that each individual was near unique. But from Simmel all the way through to Lipset, these "cross-cutting cleavages" were seen as having different implications. For Simmel, they contributed to the softening of micro- and then macro-social conflicts. For Lipset they provided a clue as to how to answer Werner Sombart's question, "Why is there no socialism in America?": the salience of multiple immigrant groups, churches, and neighborhoods has severely undermined occupation as a political driver.

With the greater emphasis on citizens and egalitarianism in the late 20th century, more attention has been given to themes like personal identity (gender, sexual orientation, environmentalism) in relation to political action and cultural commitment. This has led to an increased interest in consumption politics, such as boycotting products from firms that use underpaid labor in developing countries (e.g., Dalton, 2004).

Closer studies of participation have broken up general indexes formerly applied to all groups irrespective of their nature (as used for example by Verba and Putnam). This has been done with a view to model dynamics such as "issue specificity": the culture and dynamics of arts participation (which is rising in many countries), for instance, differs from union membership (which is falling in many areas) (Clark \& Silva, 2009). The expressive and emotional dimensions have been more actively theorized as an integral but analytically separable component of political culture that demands more careful analysis, ongoing in work by political psychologists. New questions arise in this specific field: for example, how do parades and posters, rap songs, graffiti, and blogs mobilize in face of the decline of parties and formal organizations? The Internet offers a huge source of new data, often free to download, to explore dynamics by addresses, postal codes, electoral districts, and regions and to contrast these fluxes with those occurring within nation-states. New computer-based content analysis programs can rapidly offer quantitative patterns ready for interpretation, which researchers in the humanities and computer sciences are mining, thus taking the Verba/Nie and Putnam traditions in new directions. New concepts like contexts, contingencies, and scenes are joining the older categories class, race, gender, and national belonging as units of analysis. Cultural meaning is the key to capturing such transformations.

Finally, a "strong program" in cultural sociology is taking shape (Alexander \& Smith, 1993). It proposes an interpretive yet structuralist approach to the study of political cultures, understood as rhetorical themes discursively performed by agents when "working the binaries" (e.g., portraying their adversaries as "uncivil"). From this 
neo-Durkheimian perspective, political culture emerges as a collective and symbolic phenomenon, whose understanding and explanation requires a work of "deep description." This approach has clear affinities with critical approaches developed in political anthropology (e.g., Wedeen, 2002).

Political culture analysis today has a vastly broader scope than at the time of its creation in the 1950s, encompassing individual attitudes toward government, sociocultural values and beliefs, as well as material and immaterial expressions such as flags, hymns, oral and written texts, film, just to mention a few examples. Although epistemological cleavages remain significant, separating atomistic and individualistic notions of political culture from holistic ones, the rise in interdisciplinarity and the growth of international scientific collaboration around research networks suggest that the prospects of the study of political culture are promising. It faces no less daunting challenges, however. These include a more systematic integration of knowledge produced in other fields, including both the sciences and the humanities, the inclusion of nonwestern ideas and social experiences, and a more horizontal and reflective relation with the public at large.

SEE ALSO: Democracy; Public Opinion; Social Capital; Survey Research; Values

\section{References}

Alexander, J. C., \& Smith, P. (1993). The discourse of American civil society: A new proposal for cultural studies. Theory and Society, 22(2), 151-207.

Alexander, J. C. (2006). The civil sphere. Oxford, UK: Oxford University Press.

Almond, G., \& Verba, S. (1963). The civic culture: Political attitudes and democracy in five nations. Princeton, NJ: Princeton University Press.

Almond, G., \& Verba, S. (Eds.) (1980). The civic culture revisited. Boston, MA: Little, Brown \& Co.

Banfield, E. (1958). The moral basis of a backward society. Glencoe, IL: The Free Press.

Beck, U. (2000). What is globalization? Cambridge, UK: Polity Press.

Clark, T. N., \& Hoffmann-Martinot, V. (Eds.) (1998). The new political culture. Boulder, CO: Westview.

Clark, T. N., \& Silva, F. C. (2009). Revisiting Tocqueville: Citizenship norms, political repertoires, and cultural participation. In M. Cherkaoui \& P. Hamilton (Eds.), Raymond Boudon. A life in sociology (pp. 247-278). Oxford, UK: Bardwell Press.

Dalton, R. (2004). Democratic challenges, democratic choices. The erosion of political support in advanced industrial democracies. Oxford, UK: Oxford University Press.

Dalton, R. (2008). The good citizen. How a younger generation is reshaping American politics. Washington, DC: CQ Press.

Denters, B., Gabriel, O., \& Torcal, M. (2007). Norms of good citizenship. In J. van Deth, J. Montero \& A. Westholm (Eds.), Citizenship and involvement in European democracies. A comparative analysis (pp. 88-108). London, UK: Routledge.

Elazar, D. J. (1975). The American cultural matrix. In D. J. Elazar \& J. Zikmund II (Eds.), The ecology of American political culture (pp. 13-42). New York, NY: Thomas Y. Crowell.

Inglehart, R. (1977). The silent revolution: Changing values and political styles among western publics. Princeton, NJ: Princeton University Press.

Inglehart, R. (1997). Modernization and post modernization. Princeton, NJ: Princeton University Press. 
Lewin-Epstein, N., \& Levanon, A. (2005). National identity and xenophobia in an ethnically divided society. International Journal on Multicultural Societies, 7, 90-118.

Martins, H. (1974). Time and theory in sociology. In J. Rex (Ed.), Approaches to sociology. An introduction to major trends in British sociology (pp. 246-294). London, UK: Routledge \& Kegan Paul.

Putnam, R. (1993). Making democracy work. Civic traditions in modern Italy. Princeton, NJ: Princeton University Press.

Putnam, R. (2000). Bowling alone: The collapse and revival of American community. New York, NY: Simon \& Schuster.

Silver, D., Clark, T.N., \& Yanez, C. N. (2010). Scenes: Social context in an age of contingency. Social Forces, 88(5), $2293-2324$.

Silva, F. C. (2008). Mead and modernity. Science, selfhood and democratic politics. Lanham, MD: Lexington Books.

Thompson, M. Ellis, R., \& Wildavsky, A. (1990). Cultural theory. Boulder, CO: Westview.

Wedeen, L. (2002). Conceptualizing culture: Possibilities for political culture. American Political Science Review, 96(4), 713-728.

\section{Further reading}

Achterberg, P. (2006). Considering cultural conflict. Class politics and cultural politics in western societies. Maastricht, the Netherlands: Shaker Publishers.

Alexander, A., \& Welzel, C. (2011). Measuring effective democracy: The human empowerment approach. Journal of Comparative Politics, 43, 271-289.

Coleman, J. (1988). Social capital in the creation of human capital. American Journal of Sociology, 94, $95-120$.

Erickson, B., \& Nosanchuk, T. (1990). How an apolitical association politicizes. Canadian Review of Sociology and Anthropology, 27, 206-219.

Evans, G. (1999). The end of class politics? Class voting in comparative context. Oxford, UK: Oxford University Press.

Grodach, C., \& Silver, D. (2013). The politics of urban cultural policy. Global perspectives London, UK: Routledge.

Lipset, S. M. (1996). American exceptionalism. New York, NY: W. W. Norton.

Mendras, H. (1971) The vanishing peasant. Innovation and change in French agriculture. Cambridge, MA: MIT Press.

Newton, K. (2001). Trust, social capital, civil society and democracy. International Political Science Review, 22, $201-214$.

Norris, P., \& Inglehart, R. (2004). Sacred and secular. Religion and politics worldwide. Cambridge, MA: Cambridge University Press.

Novak-Leonard, J., \& Brown, A. (2011). Beyond ttendance: A multi-modal understanding of arts participation. Washington DC: National Endowment for the Arts.

Rothstein, B., \& Stolle, D. (2008). The state and social capital: An institutional theory of generalized trust. Comparative Politics, 40, $441-459$.

Skocpol, T., \& Fiorina, M. (Eds.) (2000). Civic engagement in American democracy. Washington, DC: Brookings Institution Press.

Stolle, D., \& Rochon, T. (1998). Are all associations alike? Member diversity, associational type, and the creation of social capital. American Behavioral Scientist, 42, 47-65.

Tilly, C. (2006). Regimes and repertoires. Chicago, IL: Chicago University Press.

Tocqueville, A. de (1945). Democracy in America. New York, NY: Vintage Books. 
Verba, S., Nie, N., \& Kim, J. (1978). Participation and political equality: A seven-nation comparison. New York, NY: Cambridge University Press.

Verba, S., Schlozman, K., Brady, H., \& Nie, N. (1993). 'Citizen activity: Who participates? What do they say? American Political Science Review, 87(2), 303-318.

Welzel, C., Inglehart, R., \& Deutsch, F. (2005). Social capital, voluntary associations and collective action: Which aspects of social capital have the greatest "civic" payoff? Journal of Civil Society, $1,121-146$.

Wilson, J. (2000). Volunteering. Annual Review of Sociology, 26, 215-240.

Zukin, C., Keeter, S., Andolina, M., Jenkins, K., \& Delli Carpini, M. (2006). A new civic engagement? Political participation, civic life, and the changing American citizen. Oxford, UK: Oxford University Press.

Mónica Brito Vieira is a lecturer at the University of York. She specializes in the history of political thought and in normative political theory. She received her $\mathrm{PhD}$ from the University of Cambridge. She is the author of The Elements of Representation in Hobbes: Aesthetics, Theatre, Law and Theology in the Construction of Hobbes's Theory of the State (2009) and the co-author (with David Runciman) of Representation (2008).

Filipe Carreira da Silva is research fellow at the Institute of Social Sciences of the University of Lisbon and fellow of Selwyn College, Cambridge. His main research interests include social and political theory, intellectual history, and political sociology. He is the author of several books and articles, including the award-winning Mead and Modernity. Science, Selfhood, and Democratic Politics (2008).

Terry Nichols Clark is professor of sociology at the University of Chicago. He has taught at Columbia, Harvard, Yale, the Sorbonne, University of Florence, and University of California - Los Angeles and published some 35 books. He studies how urban cultures transform fundamental processes such as the breakdown of class politics and clientelism (in The New Political Culture), the rise of consumption and lifestyle issues (The City as an Entertainment Machine), how art can energize politics and economics (Can Tocqueville Karaoke?). These link to scenes in 42,000 US zip codes and case studies in Chicago, Paris, and other key cities. See www.faui.org, http://www.tnc-newsletter.blogspot.com/ and scenes.uchicago.edu 